\title{
ANALISIS INOVASI BIROKRASI DI UNIT PELAKSANA TEKNIS (UPT) CIMAHI TECHNO PARK
}

\author{
Dicky Febriansyah Rokhmat1), Caroline Paskarina'). \\ 1) Prodi Magister Ilmu Pemerintahan, Fakultas Ilmu Sosial dan Ilmu Politik, \\ Universitas Padjadjaran, Indonesia \\ 2) Prodi Magister Ilmu Pemerintahan, Fakultas Ilmu Sosial dan Ilmu Politik, \\ Universitas Padjadjaran, Indonesia
}

\begin{abstract}
Abstrak
Artikel berjudul Analisis Inovasi Birokrasi di Unit Pelaksana Teknis (UPT) Cimahi Techno Park bertujuan untuk menganalisis inovasi birokrasi di Unit Pelaksana Teknis Cimahi Technopark dan menganalisis faktor pendukung dan penghambat inovasi birokrasi di Unit Pelaksana Teknis (UPT) Cimahi Technopark. Metode penelitian menggunakan deskriptif dengan pendekatan kualitatif. Cara memperoleh data dilakukan dengan studi kepustakaan dan observasi. Hasil penelitian menunjukkan inovasi birokrasi di Unit Pelaksana Teknis Cimahi Technopark berada pada tipe inovasi Top Down Innovation to Bottom-up Innovation dengan tingkat inovasi, inovasi birokrasi yang dilakukan pada UPT Cimahi Technopark berada pada tingkat inovasi perbaikan layanan, inovasi sistem dan inovasi konseptual. Faktor pendukung inovasi birokrasi di Unit Pelaksana Teknis Cimahi Technopark terdiri dari kebijakan Pemerintah Pusat dan Daerah yang mendukung, infrastruktur yang memadai, ketersediaan sumber daya manusia yang melimpah, jaringan kerja sama yang sudah mulai terbentuk, adanya sumber teknologi dalam klaster, sumber permodalan dan kondisi permintaan sektor terkait. Faktor penghambat inovasi birokrasi di Unit Pelaksana Teknis Cimahi Technopark terdiri dari jumlah anggaran yang kurang, sosialisasi yang dilakukan masih belum menunjukkan hasil yang optimal, perkembangan industri bisnis digital sangat dinamis, Jumlah SDM pengelola sarana prasarana pendukung masih kurang seiring dengan jumlah anggaran yang kurang dan minimnya sertifikasi dana akreditasi untuk pelaksana Creative Business Digital.
\end{abstract}

Kata Kunci: Inovasi, Birokrasi, Cimahi Techno Park.

\begin{abstract}
The Analysis of Bureaucratic Innovation at the Cimahi Techno Park Technical Implementation Unit (UPT) aims to analyze bureaucratic innovation in the Cimahi Technopark Technical Implementation Unit and analyze the supporting and inhibiting factors of bureaucratic innovation at the Cimahi Technopark Technical Implementation Unit (UPT). The research method uses a descriptive qualitative approach. How to obtain data is done by literature study and observation. The results showed that bureaucratic innovation in the Cimahi Technopark Technical Implementation Unit was in the Top Down Innovation to Bottom-up Innovation type with a level of innovation, bureaucratic innovation carried out at UPT Cimahi Technopark was at the level of service improvement innovation, system innovation and conceptual innovation. The supporting factors for bureaucratic innovation in the Cimahi Technopark Technical Implementation Unit consist of supporting central and regional government policies, adequate infrastructure, availability of abundant human resources, cooperative networks that have begun to form, the presence of technology resources in clusters, capital sources and demand conditions. related
\end{abstract}


sectors. The inhibiting factors for bureaucratic innovation at the Cimahi Technopark Technical Implementation Unit consisted of a lack of budget, the socialization that was carried out had not shown optimal results, the development of the digital business industry was very dynamic, the number of human resources managing supporting infrastructure was still lacking in line with the lack of budget certification of accreditation funds for Creative Business Digital implementers.

Keywords: Innovation, Bureaucratic, Cimahi Techno Park.

\section{PENDAHULUAN}

Keberadaan techno park atau taman sains di Indonesia diperkuat dengan program Nawa Cita 2014-2019. Technopark merupakan salah satu prioritas pemerintahan presiden dan wakil presiden terpilih periode 20142019 yang tertuang dalam Nawa Cita. Nawa Cita menyebutkan bahwa akan meningkatkan produktivitas rakyat dan daya saing di pasar internasional, sehingga bangsa Indonesia bisa maju dan bangkit bersama bangsa-bangsa Asia lainnya (Program Nawacita Keenam). Salah satu penjabaran prioritas Nawa Cita tersebut yaitu membangun sejumlah Science dan Technopark di daerah-daerah, politeknik dan SMK-SMK dengan prasarana dan sarana dengan teknologi terkini. Urgensi mendirikan 100 Techno park menjadi kebutuhan sangat penting agar Indonesia bisa bertahan dan bersaing dalam persaingan global. Techno Park akan memberi kontribusi besar bagi pertumbuhan perekonomian nasional.

Kota Cimahi menjadi salah satu dari 100 kota di Indonesia yang memiliki sains dan techno park. Pembangunan techno park di kabupaten/kota oleh kementerian/Lembaga sesuai dengan kompetensi, tugas pokok dan fungsinya. Dalam RPJMN 2015-2019, Kota Cimahi menjadi salah satu kota yang terpilih dalam pembangunan technopark. Kota Cimahi merupakan salah satu kota yang menyambut baik rencana Techno Park. Hal ini sejalan dengan visi Kota Cimahi "Kreatif" di segala bidang khususnya bidang industri kreatif. Berdasarkan Peraturan Wali Kota Cimahi Nomor 14 Tahun 2018 tentang Cimahi Techno Park Sebagai Kawasan Sains dan Teknologi Pasal 1 Ayat (8), Unit Pelaksana Teknis (UPT) Cimahi Techno Park (CTP) adalah lembaga atau instansi yang mempunyai tugas pokok untuk melaksanakan sebagian tugas teknis dari Dinas Perdagangan Koperasi UKM dan Perindustrian dalam pengelolaan Cimahi Techno Park serta kebijakan 
yang ditetapkan oleh Kepada Dinas. UPT Cimahi Techno Park merupakan pengelola kawasan sains dan teknologi (KST) di Kota Cimahi. KST Cimahi Techno Park terdiri dari dua kawasan gedung yaitu pertama Gedung Cimahi Technopark dan kedua Gedung Baros Information Technology Creative (BITC). Kedua fasilitas gedung tersebut memiliki fungsi yang berbeda, namun berada dalam satu birokrasi, yaitu di bawah pengelolaan Unit Pelaksana Teknis Cimahi Techno Park. Gedung Cimahi Technopark memiliki fungsi untuk memfasilitasi kegiatan inkubasi bisnis para pelaku usaha dan juga sarana bagi kegiatan-kegiatan yang dilakukan masyarakat atau perangkat daerah di Kota Cimahi. Sementara Gedung Baros Information Technology Creative (BITC) memiliki fungsi sebagai akselerasi bisnis dengan co-working space untuk para pengusaha pemula.

Techno Park memiliki beberapa fasilitas, antara lain inkubator bisnis, angel capital, seed capital dan venture capital. Dalam birokrasi, tidak terlepas dari peran berbagai aktor. Stakeholder di Cimahi Techno Park adalah pemerintah Pusat dan Daerah, komunitas peneliti (akademis), komunitas bisnis dan media yang saling bekerja sama untuk mengintegrasikan penggunaan dan pemanfaatan technopark. Sebagai hub untuk membangun sinergi dan pertumbuhan interaksi antar unsur kelembagaan IPTEK (Akademisi-Bisnis-Pemerintah-Komunitas-Media), UPT Cimahi Technopark memberikan layanan kepada masyarakat di bidang pemanfaatan ilmu pengetahuan dan teknologi yang tidak semata-mata bersifat profit oriented, pelayanan di bidang pendidikan dan pelatihan ketenagakerjaan, pelayanan bidang riset dan pengembangan ilmu pengetahuan dan teknologi, pengembangan UKM / penumbuhan wirausaha baru berbasis teknologi dan wisata edukasi. Seluruh layanan tersebut dapat berjalan dengan birokrasi yang digerakan oleh sumber daya yang ada di UPT Cimahi Technopark.

Unit Pelaksana Teknis Cimahi Techno Park pada tahun 2019 memfasilitasi 337 kegiatan di Gedung Cimahi Technopark. Selain itu, terdapat 25 tenant inkubasi bisnis yang dibina oleh Dinas Perdagangan, Koperasi, Perindustrian dan UKM Kota Cimahi. Seluruh tenant tersebut dibina oleh Disdagkoperin Kota Cimahi di Gedung Cimahi Technopark 
dalam mengembangkan usahanya. Terdapat beraga usaha yang dijalankan, di antaranya mengembangkan sistem aplikasi, menghasilkan produk digital kreatif, mengembangkan bisnis model, Bidang Engineering/Teknologi khususnya mechanical dan electrical, memiliki layanan jasa di bidang product branding dan film.

Permasalahan yang muncul yaitu Berkembangnya bidang pelayanan Unit Pelaksana Teknis Cimahi Techno Park mengarahkan pengelola kawasan untuk melakukan inovasi agar kebutuhan penerima manfaat atau konsumen dalam hal ini masyarakat dan perangkat daerah dapat terpenuhi. Atas perkembangan kebutuhan tersebut, Unit Pelaksana Teknis Cimahi Techno Park melakukan beberapa inovasi birokrasi pada tingkat sistem, perbaikan pengelolaan dan tingkat konsep, yaitu dengan berkolaborasi dengan pilar penta helix, mengembangkan sistem aplikasi untuk perizinan peminjaman fasilitas di UPT Cimahi Techno Park dan memfasilitasi pengembangan bisnis para pelaku usaha dengan membantu pemasaran produk secara online termasuk dengan pembuatan desain produk. Berdasarkan uraian latar belakang tersebut, penulis memiliki ketertarikan untuk menganalisis inovasi birokrasi yang dilaksanakan oleh Unit Pelaksana Teknis Cimahi Techno Park. Untuk itu penulis membuat rumusan masalah, yaitu pertama bagaimana gambaran umum Unit Pelaksana Teknis (UPT) Cimahi Technopark?; kedua, bagaimana inovasi birokrasi di Unit Pelaksana Teknis (UPT) Cimahi Technopark?; ketiga, apa saja faktor pendukung inovasi birokrasi di Unit Pelaksana Teknis (UPT) Cimahi Technopark?; dan keempat, apa saja faktor penghambat inovasi birokrasi di Unit Pelaksana Teknis (UPT) Cimahi Technopark?. Tujuan penelitian ini yaitu untuk menganalisis inovasi birokrasi di Unit Pelaksana Teknis (UPT) Cimahi Technopark dan menganalisis faktor pendukung dan penghambat inovasi birokrasi di Unit Pelaksana Teknis (UPT) Cimahi Technopark.

Menurut Blau (Blau dalam Kumorotomo, Wahyudi, 2008) birokrasi adalah organisasi yang memaksimumkan efisiensi dalam administrasi sekaligus yang menyarankan agar istilah ini digunakan secara netral untuk mengacu kepada aspek-aspek administratif dari organisasi. Birokrasi sesungguhnya 
dimaksudkan sebagai sarana bagi pemerintah yang berkuasa untuk melaksanakan pelayanan politik sesuai dengan aspirasi masyarakat. Birokrasi mula-mula dibentuk supaya keputusan-keputusan pemerintah dapat dilaksanakan dengan sistematis melalui aparat-aparat negara. Keputusan-keputusan politik hanya akan bermanfaat bagi setiap warga negara jika pemerintah mempunyai birokrasi yang tanggap, sistematis dan efisien. Birokrasi juga dapat digunakan sebagai alat pembaruan. Ini akan terlaksana bila tujuan-tujuan organisasi memang diarahkan kepada strategi pembaruan dan pembangunan. Untuk dapat merealisasi cita-cita pembangunan sosial ekonomi, pemerintah harus memiliki pranata-pranata yang mudah menerima inovasi-inovasi baru yang bermanfaat bagi pembangunan.

Menurut pendapat Irwan (Irwan, 2010) bahwa untuk melakukan inovasi perlu yakin bahwa inovasi tersebut akan memberikan keuntungan dari berbagai segi. Rogers dalam Irwan menyampaikan bahwa beberapa karakteristik intrinsik inovasi yang mempengaruhi keputusan individu untuk mengadopsi atau menolak inovasi di antaranya keunggulan relatif, kompabilitas, kerumitan, kemampuan diuji coba dan kemampuan diamati. Dalam perspektif lain, Mulgan (Mulgan dan Albury, 2003) mengemukakan beberapa elemen utama dalam proses inovasi, yaitu generating posibilities, incubating dan prototyping, replicating dan scalling up, analysing dan evaluate. Dari beberapa pendapat tersebut penulis melihat bahwa pada dasarnya inovasi merupakan perubahan. Inovasi merupakan perubahan dengan upaya untuk mengembangkan sebuah konsep menjadi lebih dapat diaplikasikan dan memberikan manfaat untuk memecahkan masalah. Di dalam inovasi terdapat tahap generalisasi kemungkinan inovasi, inkubasi, mengamati, meniru dan modifikasi. Untuk itu tujuan utama dari inovasi adalah memecahkan masalah yang dihadapi.

Irwan berpendapat bahwa terdapat dua dimensi yang melingkupi inovasi, yaitu dimensi daya saing dan dimensi toleransi risiko. Dimensi daya saing berkaitan dengan budaya organisasi dan kecenderungan sikap inovatif individu dalam organisasi. Sementara dimensi toleransi risiko berkaitan dengan kesanggupan biaya yang dikeluarkan organisasi untuk 
membiayai penelitian dan pengembangan inovasi. Dari dua dimensi tersebut dapat dipetakan posisi inovasi pada beberapa kuadran, yaitu reactive innovation, incremental innovation, anticipatory or explanatory dan radical innovation. Berbeda dengan Irwan, Turrel (Turrel dalam Irwan, 2010) melihat inovasi dari dua dimensi yang berbeda, yaitu dimensi internal inovasi dan dimensi eksternal inovasi. Untuk itu, akar dari meningkatnya daya saing nasional adalah menumbuh kembangkan inovasi dari tingkat organisasi perangkat daerah sebagai lingkungan internal dan di setiap pemerintahan daerah sebagai lingkungan eksternal. Dengan inovasi, pemerintah pusat maupun daerah diharapkan mampu menghadapi tantangan dan permasalahan yang ada seperti tuntutan peningkatan kualitas pelayanan publik, serta rendahnya kepercayaan publik dan dunia usaha terhadap birokrasi.

Sementara itu pendapat lain dari Osborne dan Brown (Osborne dan Brown, 2005) menyederhanakan proses inovasi dalam tiga tahapan utama yaitu invention stage, implementation stage, dan diffusion stage. Salah satu faktor pendorong munculnya aksi inovasi pada organisasi pemerintah adalah adanya perubahan tuntutan peningkatan kualitas pelayanan dari lingkungan eksternal maupun stakeholder dan juga didorong oleh kebijakan yang diterapkan oleh pemerintah pusat melalui agenda program percepatan reformasi birokrasi. Salah satu agenda dari reformasi birokrasi ini dilakukan melalui program inovasi pelayanan publik. Menurut Immanudin (Imanuddin, 2016) target yang hendak dicapai dari program ini adalah citacita pemerintahan kelas dunia (World Class Government) yang diharapkan dapat terwujud pada tahun 2025. Tantangan penyelenggaraan pemerintahan daerah di era globalisasi menuntut pemerintah daerah melakukan inovasi. Pemerintah dalam beberapa regulasi juga menekankan pentingnya kepala daerah melakukan inovasi untuk mendorong efektivitas pelayanan publik, menciptakan nilai tambah, serta tetap terbuka pada persaingan domestik dan internasional.

Menurut De Vries (De Vries, dkk, 2018) inovasi dipengaruhi beberapa faktor-faktor yang dapat mendukung atau menjadi penghambat yang dikategorikan pada empat tingkatan, yaitu: 
a. Tingkat lingkungan, meliputi tuntutan publik/perhatian media, partisipasi dalam jaringan, aspek regulasi, kompatibilitas lembaga mengadopsi inovasi yang sama dan persaingan dengan organisasi lain.

b. Tingkat organisasi, meliputi sumber daya, gaya kepemimpinan, tingkat risiko keengganan/ruang untuk belajar, insentif, konflik dan struktur organisasi.

c. Tingkat inovasi, meliputi kemudahan dalam penggunaan inovasi, keuntungan relatif, kesesuaian dan trialability.

d. Tingkat individu/karyawan, meliputi otonomi karyawan, posisi organisasi, pengetahuan dan keterampilan kerja, kreativitas, aspek demografis, komitmen/kepuasan dengan pekerja, perspektif dan normanorma bersama, inovasi penerimaan, hasil inovasi sektor publik, efektivitas, efisiensi, mitra swasta yang terlibat, warga yang terlibat dan meningkatkan kepuasan pelanggan.

Pendapat dari De Vries, dkk tersebut dapat merangkum beberapa pendapat dari para ahli yang telah disebutkan sebelumnya. Penulis menilai bahwa faktor lingkungan, organisasi, tingkat inovasi dan individu memiliki keterkaitan dalam membangun iklim inovasi di pemerintah daerah. Untuk itu guna menguraikan faktor-faktor yang menghambat inovasi Pemerintah Daerah akan dilandasi pemikiran pada tingkatan faktor inovasi yaitu tingkat lingkungan, tingkat organisasi, tingkat inovasi dan tingkat individu. Tingkatan inovasi tersebut akan dapat membantu mendeskripsikan tipe inovasi yang dilakukan pada Unit Pelaksana Teknis Cimahi Techno Park.

Pada dasarnya inovasi merupakan perubahan yang mengarah kepada keadaan lebih baik dengan terpecahkannya masalah. Menurut Makmur dan Thahir (Makmur dan Thahir, 2012) inovasi didefinisikan sebagai suatu proses kegiatan atau pemikiran manusia untuk menemukan sesuatu yang baru yang berkaitan dengan input, proses dan output, serta dapat memberikan manfaat dalam kehidupan manusia. Inovasi yang berkaitan dengan input artinya sebagai pola-pola pemikiran atau ide manusia yang disumbangkan pada temuan baru. Adapun inovasi yang berkaitan dengan proses banyak berorientasi pada metode, teknik, ataupun cara bekerja dalam rangka 
menghasilkan sesuatu yang baru. Selanjutnya, Makmur dan Thahir (Makmur dan Thahir, 2012) menjelaskan inovasi yang berkaitan dengan output berdasarkan definisi tersebut lebih ditujukan pada hasil yang telah dicapai terutama penggunaan pola pemikiran dan metode atau teknik kerja yang dilakukan.

Menurut Kurniawan (Kurniawan, 2017) inovasi pada sektor birokrasi publik harus dapat memberikan dampak berupa layanan publik yang lebih profesional, efektif, sederhana, transparan, terbuka, tepat waktu, responsif dan adaptif serta sekaligus dapat membangun kualitas manusia dalam arti meningkatkan kapasitas individu dan masyarakat untuk secara aktif menentukan masa depannya sendiri. Samson (dalam Anatan, Lina dan Ellitan, 2009) menerangkan salah satu alasan mengapa inovasi sangat diperlukan karena cepatnya perubahan lingkungan organisasi yaitu semakin dinamis, sehingga sebuah organisasi harus bisa mengelola inovasi sebagai penentu keberhasilan organisasi untuk menjadi kompetitif. Berdasarkan beberapa pendapat di atas, penulis dapat menyimpulkan bahwa untuk menghasilkan dampak perbaikan terhadap birokrasi, inovasi pada sektor birokrasi perlu memiliki nilai kompetitif yang dapat disandingkan, sehingga daya saingnya akan mampu meningkatkan taraf inovasi.

Halversen membagi tiga tipe spektrum inovasi dalam sektor publik meliputi:

a. Tipe inovasi Incremental Innovation To Radical Innovation atau Inovasi Inkremental menuju inovasi radikal. Tipe inovasi inkremental menuju radikal ditandai oleh tingkat perubahan, perbaikan sedikit demi sedikit secara teratur terhadap produk inovasi dalam proses layanan yang sudah ada. Incremental innovation hanya dibangun berdasarkan apa yang sudah ada. Misalnya dalam bidang pelayanan publik pada administrasi kependudukan dan pencatatan sipil yang semula pendaftaran dilakukan secara manual, sekarang dapat dikembangkan menjadi daring, sehingga menghilangkan antrean dan pelayanan menjadi lebih efisien.

b. Tipe Inovasi Top Down Innovation To Bottom-up Innovation merupakan inovasi yang ditandai oleh aktor yang mengawali proses 
mengarah kepada perubahan perilaku dari top manajemen atau organisasi atau institusi di dalam hierarki. Perubahan tersebut merupakan visi pimpinan yang diturunkan kepada para pekerja di tingkat bawah seperti pegawai negeri, pelayanan masyarakat, dan pembuat kebijakan di level menengah). Contohnya visi misi kepala daerah yang dituangkan dalam bentuk kebijakan atau program pemerintah daerah. Pada bentuk inovasi top down, top manajemen menekankan kepada kerangka inovasi. Sementara pelaksana mempertajam sasaran inovasi sesuai dengan permasalahan yang dihadapi.

c. Tipe Inovasi Need Led Innovation to Efficiency Innovation atau inovasi terarah menuju efisiensi inovasi. Tipe inovasi ini ditandai proses yang diawali untuk menyelesaikan masalah spesifik agar inovasi layanan atau prosedur yang sudah ada lebih efisien. Tipe inovasi efisiensi berfokus pada peningkatan apa yang sudah ada, misalnya alur kerja, produksi, atau proses bisnis. Inovasi semacam itu dapat menghasilkan peningkatan besar dalam kinerja dan efisiensi bisnis. Inovasi efisiensi mengambil bentuk inovasi berupa perbaikan proses atau model bisnis yang lebih efisien. Inovasi ini memungkinkan birokrasi untuk menyederhanakan dan merampingkan proses yang ada, memproduksi layanan yang sudah ada dengan biaya lebih rendah dan menghasilkan layanan kepada pelanggan yang sudah ada dengan keunggulan, misalnya harga lebih rendah.

Dari tiga tipe inovasi tersebut, Halverson (dalam Nurdin, 2016) memberikan rincian tipe inovasi dalam sektor publik di antaranya berupa layanan baru atau perbaikan layanan, inovasi proses, inovasi administrasi, inovasi sistem, inovasi konseptual dan perubahan radikal yang bersifat rasional. Pada inovasi layanan baru atau perbaikan layanan contohnya pelayanan puskesmas rawat inap. Contoh dari inovasi administrasi yaitu penggunaan instrumen kebijakan baru sebagai hasil dari sebuah perubahan kebijakan. Inovasi pada sistem berupa sistem baru atau perubahan fundamental dari sistem yang ada dengan menetapkan 
organisasi baru atau pola kerja sama atau interaksi baru. Inovasi pada konseptual berupa perubahan dalam memandang aktor seperti perubahan dicapai dengan menggunakan konsep baru, misal pengintegrasian pengelolaan sumber daya. Sementara perubahan radikal berupa perubahan cara pandang atau pergeseran mental pegawai dari sebuah organisasi atau sasaran inovasi. Dari pendapat tersebut dapat dimaknai bahwa inovasi birokrasi merupakan kesatuan utuh antara instrumen kebijakan, aktor perubahan dan pengelolaan sumber daya.

Menurut Mulgan dan Albury (Mulgan dan Albury, 2003) inovasi juga dapat dimanfaatkan untuk mengembangkan strategi dan tindakan dalam pelayanan publik. Inovasi juga merupakan instrumen untuk mengembangkan cara-cara baru dalam menggunakan sumber daya dan memenuhi kebutuhan secara lebih efektif. Organisasi birokrasi senantiasa mendapatkan nilai negatif karena banyak persoalan yang belum teratasi sementara pada saat yang bersamaan tuntutan dan kebutuhan masyarakat terus berkembang. Sementara itu keberanian para pejabat untuk berinovasi juga rendah karena insentif rendah yang diperoleh dari inovasinya dan pada saat yang sama risiko yang besar dihadapi jika terjadi kegagalan dalam berinovasi. Namun demikian, dalam konteks pemerintah daerah di Indonesia, inovasi merupakan suatu amanat dari Undang-Undang Nomor 23 Tahun 2014 tentang Pemerintahan Daerah karena pada pasal 389 bahwa "Dalam hal pelaksanaan inovasi yang telah menjadi kebijakan Pemerintah Daerah dan inovasi tersebut tidak mencapai sasaran yang telah ditetapkan, aparatur sipil negara tidak dapat dipidana”. Pasal tersebut sejatinya mendukung para pegawai negeri di daerah untuk dapat melakukan inovasi bahkan meningkatkan inovasinya.

\section{METODE PENELITIAN}

Metode yang digunakan dalam makalah ini adalah deskriptif dengan pendekatan kualitatif. Subjek yang diteliti yaitu Unit Pelaksana Teknis (UPT) Cimahi Techno Park. Cara memperoleh data dilakukan dengan studi kepustakaan dan observasi. Studi Pustaka dilakukan dengan meninjau 
dokumen-dokumen terkait inovasi birokrasi di Unit Pelaksana Teknis (UPT) Cimahi Techno Park. Observasi dilakukan dengan cara partisipatif pasif karena penulis dapat langsung mengamati kegiatan birokrasi yang dilakukan di Unit Pelaksana Teknis (UPT) Cimahi Techno Park.

\section{PEMBAHASAN}

\section{Gambaran Umum Unit Pelaksana Teknis (UPT) Cimahi Techno Park.}

Berdasarkan Peraturan Wali Kota Cimahi Nomor 35 Tahun 2018 tentang Unit Pelaksana Teknis Cimahi Technopark dan berdasarkan Dokumen Master Plan Cimahi Technopark UPT Cimahi Techno Park memiliki tugas pokok dan fungsi meliputi :

a. Penyusunan program kerja dan perencanaan pengelolaan Cimahi Techno Park, pelaksanaan operasional kegiatan penyediaan dan pemeliharaan fasilitas sarana dan prasarana kawasan Cimahi Techno Park.

b. Pelaksanan kegiatan penyewaan sarana dan prasarana Cimahi Techno Park.

c. Pelaksanaan koordinasi dan kerjasama pengembangan Cimahi Techno Park dengan instansi terkait.

d. Pelaksanaan pembinaan dan pengembangan sumber daya manusia dalam lingkup tugas dan tanggung jawabnya.

e. Pelaksanaan urusan tata usaha, keuangan, kepegawaian dan perlengkapan.

f. Pelaksanaan evaluasi dan pelaporan pelaksanaan tugas.

g. Pelaksanaan tugas yang diberikan oleh atasan sesuai dengan bidang tugasnya.

Lembaga pengelola technopark bertanggung jawab untuk melaksanakan fungsi technopark sebagaimana yang diamanatkan dalam 
perundangan. Lembaga ini harus berperan menjadi jembatan yang menghubungkan antara kepentingan pemerintah (dalam bentuk kebijakan) dengan para pemangku kepentingan (stakeholder) yang menerima manfaat dari kebijakan tersebut. Lembaga pengelola harus mendorong adanya penerapan teknologi yang dihasilkan lembaga penghasil teknologi dan mendiseminasikan kepada masyarakat (pelaku usaha, terutama UMKM) yang membutuhkannya, agar UMKM memiliki daya saing yang tinggi. Selain itu, lembaga pengelola juga harus menjadi jembatan untuk mengadvokasi, melatih dan menjadi tempat magang bagi pelaku usaha, UMKM dan masyarakat luas. Pada sisi lain, technopark di berbagai negara maju didorong untuk menjadi tempat tumbuhnya perusahaan pemula berbasis teknologi. Sehingga menyiapkan tempat dan sarana untuk melakukan inkubasi usaha pemula harus menjadi bagian penting dari keberadaan technopark. Peran penting inilah yang harus dijalankan oleh pengelola technopark.

Birokrasi yang dilakukan pada UPT Cimahi Technopark berkaitan dengan jenis-jenis pelayanan yang disediakan. Ada pun jenis-jenis pelayanan yang disediakan meliputi penyewaan sarana dan prasaran kawasan Cimahi Technopark, pengembangan dan pengembangan sumber daya manusia lingkup tugas dan tanggung jawab, koordinasi dan kerja sama pengembangan technopark dan tugas lainnya yang diberikan Kepala Dinas. Dalam memberikan pelayanan kepada masyarakat dan juga perangkat daerah, UPT Cimahi Technopark memiliki ruangan dan aset yang dapat disewa dan menjadi sumber retribusi, di antaranya Ruang Convention Hall, Ruang Kelas, Ruang Komputer Multimedia, Jogging Track, Creative Corner dan Co-working space. Alur birokrasi yang terdapat dalam pelayanan UPT Cimahi Technopark dilakukan dengan melakukan inovasi berupa perizinan secara online atau daring.

\section{Analisis Inovasi Birokrasi Di Unit Pelaksana Teknis (UPT) Cimahi Techno Park.}

Inovasi birokrasi yang terdapat di UPT Cimahi Technopark berada pada tipe inovasi Top Down Innovation to Bottom-up Innovation. Hal tersebut 
ditunjukan dengan awal berdirinya technopark yang merupakan visi dari Presiden untuk mendirikan 100 taman sains untuk meningkatkan daya saing nasional di tingkat global. Technopark merupakan salah satu prioritas pemerintahan Presiden dan Wakil Presiden terpilih periode 20142019 yang tertuang dalam Nawacita. Nawa cita menyebutkan bahwa akan meningkatkan produktivitas rakyat dan daya saing di pasar internasional, sehingga bangsa Indonesia bisa maju dan bangkit bersama bangsa-bangsa Asia lainnya. Salah satu penjabaran prioritas Nawa Cita tersebut adalah membangun sejumlah Science dan Techno park di daerah-daerah, politeknik dan SMK-SMK dengan prasarana dan sarana dengan teknologi terkini. Pembangunan Taman Tekno di kabupaten/kota oleh kementerian/Lembaga sesuai dengan kompetensi, tugas pokok dan fungsinya. Dalam RPJMN 2015-2019, Kota Cimahi menjadi salah satu kota yang terpilih dalam pembangunan technopark. Kota Cimahi merupakan salah satu kota yang menyambut baik rencana Techno Park. Hal ini sejalan dengan visi Kota Cimahi "Kreatif" di segala bidang khususnya bidang industri kreatif.

Usulan inovasi birokrasi di UPT Cimahi Technopark yang diawali dengan tipe inovasi top down kemudian dikembangkan dengan inovasi yang bersumber dari inovator pada tingkat pelaksana aparatur. Kemudian pada tingkat inovasi, inovasi birokrasi yang dilakukan pada UPT Cimahi Technopark berada pada tingkat inovasi perbaikan layanan, inovasi sistem dan inovasi konseptual. Indikasi tingkatan inovasi tersebut diperoleh dari beberapa inovasi yang terdapat di UPT Cimahi Technopark di antaranya Kolaborasi Antar Empat Pilar Di Cimahi Technopark (Katerpillar Hi-Park), LKA CTP dan Sistem Peminjaman sarana dan prasarana gedung via website dan aplikasi.

Inovasi briokrasi Katerpillar Hi-Park dilatar belakangi upaya pengembangan ekonomi lokal di Kota Cimahi yang merupakan salah satu isu strategis sekaligus permasalahan utama yang harus menjadi prioritas di dalam penanganannya, para pelaku Industri Kecil Menengah (IKM) maupun Usaha Kecil Menengah (UKM) telah terbukti mampu bertahan dan tetap eksis, di tengah berbagai krisis ekonomi, sosial maupun politik yang datang 
silih berganti. Melihat fenomena tersebut, Pemerintah Kota Cimahi sangat fokus dan konsisten di dalam upaya pengembangan ekonomi lokal khususnya bagi para pelaku IKM/UKM eksisting, maupun upaya-upaya untuk melahirkan wirausaha baru berbasis inovasi dan teknologi. Kebijakan ini tentu sangat sejalan dengan kondisi Kota Cimahi yang nyaris tidak memiliki potensi Sumber Daya Alam (SDA) namun di sisi lain memiliki Sumber Daya Manusia (SDM) yang cukup melimpah. Dengan luas wilayah Kota Cimahi yang hanya 42 ha dan jumlah penduduk sebanyak 586.580 jiwa (data pada tahun 2016), maka dapat disimpulkan bahwa Kota Cimahi memiliki tingkat kepadatan penduduk yang cukup tinggi.

Hasil dari inovasi Katerpillar Hi-Park menciptakan kolaborasi antara Cimahi Technopark dan para pelaku IKM/UKM di Cimahi Technopark dengan para Stakeholder. Para pelaku IKM/ UKM di Kota Cimahi sudah dapat memanfaatkan teknologi, sehingga sulit melakukan inovasi terhadap produk-produk unggulannya. Adanya penggunaan animasi sebagai media promosi. Tersedianya fasilitas yang respresentatif, yaitu Ruang pusat layanan konsultasi bisnis dan teknologi dan layanan informasi bagi IKM/UKM, Ruang Purwarupa (prototype) \& Ruang Pamer produk unggulan IKM/UKM, Ruang layanan konsultasi pembuatan video animasi sederhana bagi pelaku IKM/UKM, Ruang pelatihan/pemagangan, Ruang Lab. Komputer Multimedia Kantor Bersama (co-working space), Sarana olahraga (Outdoor Gym, Jogging Track dan Lapangan Futsal), Creative Corner, Convention Hall, Ruang Kantor, Studio dubbing, mixing dan mastering audio, Internet,dll dan terintegrasinya dan terdokumentasikannya kegiatan - kegiatan pelaku ekonomi kreatif mulai dari pelatihan, fasilitasi, festival berjumlah 337 kegiatan.

Inovasi birokrasi Katerpillar Hi-Park berada pada tingkatan inovasi konseptual. Kolaborasi Pemerintah Daerah dengan akademisi, bisnis, komunitas dan media menciptakan hubungan simbiosis mutualisme yang dapat memberikan kemudahan dalam birokrasi. Pemerintah daerah Kota Cimahi mendukung inovasi tersebut dengan memberikan kemudahan 
dalam perizinan dan akselerasi serta pendampingan kepada para pelaku UKM melalui kegiatan inkubasi bisnis.

Inovasi LKA CTP dilatarbelakangi untuk menyediakan layanan konsultasi/layanan teknologi bagi potensi yang sedang dikembangkannya. Ada 2 (dua) program utama yang didirikan oleh Pemerintah Kota Cimahi, yaitu Inkubasi Teknologi bagi para pelaku start up (Perusahaan Pemula Berbasis Teknologi) dan juga Akselerasi bari para UKM Inovatif. Pendampingan dan pembinaan para pelaku UKM memang didukung oleh anggaran Dinas Perdagangan Koperasi UKM dan Perindustrian Kota Cimahi, namun untuk layanan yang bersifat teknis dan berkelanjutan Cimahi Techno Park dengan potensi pelaku desain dan animasi yang melimpah, berusaha untuk mendukung perkembangan usaha UKM Inovatif melalui Layanan desain kemasan dan desain video promosi produk. Semula layanan ini dilaksanakan oleh SDM Cimahi Techno Park, namun dengan konsultasi, koordinasi maka pada masa depan layanan ini akan beririsan langsung dengan para start up yang ada di Cimahi Techno Park (baik di Gedung Cimahi Techno Park maupun di Gedung BITC). Update dan Upgrade layanan ini terus dilakukan. Pada masa pandemi covid-19 ini, dimana seluruh UKM sedang mengalami penurunan omzet, maka promosi yang baik dari sisi Social Media harus dilakukan dan ini bisa didukung oleh Layanan Konsultasi Animasi dan Video Promosi oleh Cimahi Techno Park.

Dengan layanan tersebut, maka para pelaku UKM Inovatif dapat menggencarkan promosi melalui IG, Youtube, Facebook, Twitter dan sosial media lainnya untuk meningkatkan omzet ataupun hanya untuk menaikan ekuitas merek produk yang akan bermanfaat baik di masa pandemi maupun saat pandemi telah berakhir dan daya beli masyarakat kembali normal dan meningkat. Layanan ini merupakan gambaran dasar dari potensi klaster animasi dan telematika yang ada pada Kawasan Cimahi Techno Park yang disambungkan dengan kebutuhan atas promosi produk dari para pelaku UKM di Kota Cimahi. Berdasarkan masterplan Cimahi Techno Park dan Road Map pengembangan klaster inovasi bisnis digital kreatif yang disepakati bersama oleh Pemerintah Kota Cimahi, Badan 
Pengkajian dan Penerapan Teknologi Republik Indonesia, dan Kementerian Riset dan Teknologi, bahwa kolaborasi yang dilakukan harus mendukung program utama (Inkubasi dan Akselerasi), untuk itu kolaborasi antara Akademisi-Bisnis-Komunitas-Pemerintah-Media (ABCGM) pada layanan ini sangat erat dan akan menjadi simbiosis mutualisme bagi semua pihak yang bergabung di dalamnya. Hasil manfaat dari inovasi LKA CTP yaitu dapat menyediakan konten promosi yang sangat dibutuhkan para pelaku usaha Kota Cimahi berdasarkan potensi animator yang melimpah di Kota Cimahi. Ada pun konten promosi yang dihasilkan berupa Poster, Banner, Desain Kemasan, Video Profil Produk, Foto Produk, Video Animasi dan Copywriting.

Inovasi birokrasi Sistem Peminjaman sarana dan prasarana gedung via website dan aplikasi dilatarbelakangi tugas pokok Cimahi Technopark untuk melaksanakan sebagian tugas teknis pada Dinas Perdagangan Koperasi UKM dan Perindustrian dalam pengelolaan Cimahi Techno Park yang mengembangkan ekonomi kreatif yang merupakan wahana pengembangan dan pemanfaatan ilmu pengetahuan dan teknologi untuk mendorong pertumbuhan ekonomi kreatif yang terdiri dari 16 subsektor ekonomi kreatif, di antaranya aplikasi dan game developer, arsitektur, desain interior, desain komunikasi visual, desain produk, fashion, flm, animasi dan video, fotograf, kriya, kuliner, music, penerbotan, periklanan, seni pertunjukan, seni rupa, televise dan radio dan untuk kegiatan SKPD Kota Cimahi. Pada tahun 2019 jumlah kegiatan di UPT. Cimahi Techno Park sangat padat dengan total 375 kegiatan per tahun, dan peminjam booking melalui aplikasi www.peminjaman.cimahitechnopark.id dan tidak bisa booking di hari yang sudah terisi. Sebelum ada aplikasi Cimahi Techno Park, peminjaman mengisi formulir peminjaman, semakin padatnya kegiatan maka dibuatkan website untuk peminjaman, dan untuk Handphone Android bisa download di Play Store yaitu SmartCTP untuk booking tanggal kegiatan. Di Masa Pandemi ini, Cimahi Techno Park telah dibuka kembali dan sudah mulai banyak yang booking kegiatan di website Cimahi Techno Park, dengan menerapkan protokol Covid-19 untuk kegiatan yang akan dilangsungkan, masing-masing tempat dan ruangan hanya di 
perbolehkan 50\% dari jumlah kapasitas ruangan, kecuali Convention Hall hanya di perbolehkan sebanyak 150 peserta karna di buat jarak 2 meter, Protokol Covid-19 sangat diterapkan untuk tamu sebelum masuk wajib cuci tangan dan cek suhu tubuh terlebih dahulu, setelah kegiatan ruangan steril dengan disemprot Disinfektan.

Manfaat yang dihasilkan dari inovasi birokrasi tersebut yaitu Cimahi Techno Park dapat memfasilitasi kegiatan yang berkaitan dengan 16 sub sektor Industri kreatif atau yang disebut dengan konsep kolaborasi Penta Helix (Akademisi, Bisnis, Komunitas, Pemerintah dan Media). Jumlah Valuasi Penyelenggaraan Kegiatan Kolaboratif di Gedung Cimahi Techno Park tahun 2017 sekitar Rp 10.495.848.000 dengan total kegiatan sebanyak 342 kegiatan. Tahun 2018 Valuasi Penyelenggaraan Kegiatan Kolaboratif di Gedung Cimahi Techno Park sekitar Rp 8.103.417.000 dengan total kegiatan sebanyak 325 kegiatan dan tahun 2019 Valuasi Penyelenggaraan Kegiatan Kolaboratif di Gedung Cimahi Techno Park sebesar Rp 15.835.031.000 dengan total kegiatan 375 kegiatan; Selain memfasilitasi kegiatan di Cimahi Techno Park, kawasan bisnis di Gedung BITC juga diisi oleh perusahaan-perusahaan yang bergerak di bidang IT Kreatif dengan jumlah tenant sebanyak 11 tenant. Total omzet yang dihasilkan para pelaku bisnis di Gedung BITC setiap tahunnya mencapai Rp 55 Milyar (https://www.cimahitechnopark.id/visi-dan-misi.html, 2021).

\section{Faktor Pendukung Inovasi Birokrasi di Unit Pelaksana Teknis (UPT) Cimahi Technopark.}

Sebagaimana diungkapkan Turrel (dalam Irwan, 2010) yang melihat inovasi dari dua dimensi yang berbeda, yaitu dimensi internal inovasi dan dimensi eksternal inovasi. Untuk itu, akar dari meningkatnya daya saing nasional adalah menumbuh kembangkan inovasi dari tingkat organisasi perangkat daerah sebagai lingkungan internal dan di setiap pemerintahan daerah sebagai lingkungan eksternal. Untuk itu diuraikan faktor-faktor yang mendukung inovasi birokrasi di UPT Cimahi Technopark sebagai berikut : 
a. Kebijakan Pemerintah Pusat dan Daerah yang Mendukung.

Terdapat kebijakan Pemerintah Daerah Kota Cimahi yang mendukung terlaksananya inovasi birokrasi di UPT Cimahi Technopark, seperti Perpres106 Tahun2017 tentang Kawasan Sains dan Teknologi dan Permenristek No 25 Tahun 2019 tentang Tata Kelola Penyelenggaraan KST. Terbitnya Peraturan Wali Kota Cimahi Nomor 14 Tahun 2018 tentang Cimahi Techno Park sebagai Kawasan Sains dan Teknologi Pengembangan Klaster Industri Telematika/Digital Kreatif tertuang dalam Dokumen Rencana Pembangunan Jangka Menengah Daerah (RPJMD) Kota Cimahi Tahun 2017-2022. Penempatan Lokasi Klaster yang strategis membuat Gedung Cimahi Technopark mudah diakses. Terdapat pula kemudahan perizinan bagi pelaku bisnis Digital Kreatif yang dipermudah. Fasilitas Gedung Cimahi Techno Park yang dapat digunakan gratis khususnya oleh pelaku digital kreatif adalah bentuk investasi Pemerintah Kota Cimahi terhadap perkembangan sektor digital kreatif kota Cimahi.

\section{b. Infrastruktur yang Memadai.}

Tersedia Gedung Cimahi Techno Park untuk Kawah Candra di muka Pengembangan Klaster Digital Kreatif. Selain itu tersedia Gedung BITC sebagai Pengembangan Bisnis Klaster Digital Kreatif.

c. Ketersediaan Sumber Daya Manusia yang Melimpah.

Banyaknya Jumlah Lulusan/Siswa SMK, Polteknik dan Perguruan Tinggi di Kota Cimahi. Adanya Pelaku bisnis Digital Kreatif di Kota Cimahi dalam (inwall/outwall). SDM Kawasan Sains Technopark yang solid dan terampil.

d. Jaringan kerja sama yang Sudah Mulai Terbentuk.

Terdapat 61 Stakeholders dari pilar Akademisi-Bisnis-KomunitasPemerintah-Media (A-B-C-G-M) yang berkolaborasi di Kawasan Cimahi Techno Park. Ada Hubungan Kerja sama antar tenant Pelaku Bisnis Digital Kreatif (inwall/outwall). Terwujudnya kerja sama antara 
Pemerintah Kota Cimahi dengan 12 stakeholders yang terdiri dari akademisi, bisnis dan komunitas yang dituangkan dalam MOU. Terwujudnya kerja sama di antara SMKN 2 Cimahi dengan Industri (AyenaStudio) pada kegiatan Teaching Factory.

e. Adanya Sumber Teknologi dalam Klaster.

Tersedianya 5 orang mentor bidang digital kreatif pada kawasan klaster dan tersedianya kerja sama dengan Perguruan Tinggi, Industri dan Pelaku Industri.

f. Sumber Permodalan.

Adanya Fasilitasi Akses ke Lembaga Permodalan berupa Business Matching.

g. Kondisi Permintaan Sektor Terkait.

Adanya Permintaan Pemerintah untuk produk DCD untuk Pelayanan. Ada lulusan Inkubasi yang bergerak pada Bidang Percetakan dan ada Tenant Inkubasi yang bergerak mengembangkan Internet of Things (IoT).

\section{Faktor Penghambat Inovasi Birokrasi di Unit Pelaksana Teknis (UPT) Cimahi Technopark.}

Sebagaimana diungkapkan Turrel (dalam Irwan, 2010) yang melihat inovasi dari dua dimensi yang berbeda, yaitu dimensi internal inovasi dan dimensi eksternal inovasi. Untuk itu diuraikan faktor-faktor yang menghambat inovasi birokrasi di UPT Cimahi Technopark sebagai berikut:

a. Jumlah Anggaran yang kurang.

Pengurangan anggaran besar - besaran terkait pengembangan Klaster Bisnis Digital Kreatif yang menjadi akibat dari realokasi dan refocusing anggaran penanganan covid-19.

b. Sosialisasi yang dilakukan masih belum menunjukkan hasil yang optimal. 
c. Perkembangan Industri bisnis digital sangat dinamis, sehingga permintaan selalu upgrade setiap saat. Untuk itu dituntut untuk selalu melakukan inovasi dalam sektor birokrasi publik.

d. Jumlah SDM pengelola sarana prasarana pendukung masih kurang seiring dengan jumlah anggaran yang kurang.

e. Minimnya sertifikasi dana akreditasi untuk pelaksana Creative Business Digital.

\section{KESIMPULAN}

Berdasarkan pembahasan mengenai analisis inovasi birokrasi di Unit Pelaksana Teknis Cimahi Technopark di atas, penulis dapat memberikan simpulan bahwa Inovasi birokrasi di Unit Pelaksana Teknis Cimahi Technopark berada pada tipe inovasi Top Down Innovation to Bottom-up Innovation dengan tingkat inovasi, inovasi birokrasi yang dilakukan pada UPT Cimahi Technopark berada pada tingkat inovasi perbaikan layanan, inovasi sistem dan inovasi konseptual. Faktor pendukung inovasi birokrasi di Unit Pelaksana Teknis Cimahi Technopark terdiri dari kebijakan Pemerintah Pusat dan Daerah yang mendukung, infrastruktur yang memadai, ketersediaan sumber daya manusia yang melimpah, jaringan kerja sama yang sudah mulai terbentuk, adanya sumber teknologi dalam klaster, sumber permodalan dan kondisi permintaan sektor terkait. Faktor penghambat inovasi birokrasi di Unit Pelaksana Teknis Cimahi Technopark terdiri dari jumlah anggaran yang kurang, sosialisasi yang dilakukan masih belum menunjukkan hasil yang optimal, perkembangan industri bisnis digital sangat dinamis, Jumlah SDM pengelola sarana prasarana pendukung masih kurang seiring dengan jumlah anggaran yang kurang dan minimnya sertifikasi dana akreditasi untuk pelaksana Creative Business Digital. 


\section{DAFTAR PUSTAKA}

\section{Peraturan Perundang-Undangan.}

Republik Indonesia, Undang-Undang Nomor 11 Tahun 2019 Tentang Sistem Nasional Ilmu Pengetahuan Dan Teknologi.

Republik Indonesia, Undang-Undang Nomor 23 Tahun 2014 tentang Pemerintahan Daerah.

Republik Indonesia, Peraturan Pemerintah Nomor 38 Tahun 2017 Tentang Inovasi Daerah.

Republik Indonesia, Peraturan Presiden Nomor 81 Tahun 2010 tentang Grand Design Reformasi Birokrasi 2010 - 2025.

Republik Indonesia, Peraturan Wali Kota Cimahi Nomor 14 Tahun 2018 tentang Cimahi Techno Park Sebagai Kawasan Sains dan Teknologi.

Republik Indonesia, Peraturan Wali Kota Cimahi Nomor 35 Tahun 2018 tentang Unit Pelaksana Teknis Cimahi Technopark.

\section{Buku}

Anatan, Lina dan Lena Ellitan. 2009. Manajemen Inovasi (Transformasi Menuju Organisasi Kelas Dunia). Penerbit, CV. Alfabeta Bandung.

Hutagalung, Simon dan Hermawan, Dedi. 2018. Membangun Inovasi Pemerintah Daerah. Sleman: CV. Budi Utama.

Kumorotomo, Wahyudi. 2008. Etika Administrasi Negara. Raja Grafindo Persada, Jakarta.

Makmur dan Thahir, Rohana. 2012. Inovasi \& Kreativitas Manusia dalam Administrasi dan Manajemen. Refika Aditama. Bandung

Ngadisah. Pengertian dan Teori - Teori Klasik Birokrasi. Universitas Terbuka.

Osborne, S. P. dan Brown, K. 2005. Managing Change And Innovation In Public Service Organizations. Madison Ave, N.Y.: Routledge. 
Thoha, Miftah. 2005. Perilaku Organisasi : Konsep Dasar dan Aplikasinya. Jakarta: Raja Grafindo Persada.

\section{Jurnal}

Kurniawan, Robi Cahyadi. 2017. Inovasi Kualitas Pelayanan Publik Pemerintah Daerah. Jurnal FIAT JUSTISIA Universitas Lampung.

Mulgan, G. dan Albury, D. 2003. Innovation in the Public Sector, Working Paper Version 1.9. October, Strategy Unit, UK Cabinet Office.

Nurdin, Zulfa. 2016. Inovasi Kawasan Bebas Asap Rokok di Desa BoneBone Kecamatan Baraka Kabupaten Enrekang: Universitas Hasanudin Makassar.

\section{Disertasi, Tesis dan Skripsi}

Noor, Irwan. 2010. Desain Inovasi Pemerintah Daerah. Universitas Brawijaya. Disertasi.

Ernawan. 1988. Peranan Birokrasi Terhadap Peningkatan Efektifitas Pengambilan Keputusan di Perusahaan Besar. Skripsi Tidak Diterbitkan. Jakarta: Fakultas Psikologi Universitas Indonesia.

\section{Sumber Terbuka.}

Imanuddin, M. (2016, April 06). Inovasi pelayanan publik: percepatan peningkatan kualitas pelayanan publik. Kemepan-RB. Diunduh dari http://sinovik.menpan.go.id/index.php/site/article/223.

Program Nawa Cita Tahun 2014 - 2019 Poin Keenam. Diakses melalui https: / /kominfo.go.id/index.php/content/detail/5629/NAWACITA\%3A +9+Program+Perubahan+Untuk+Indonesia/0/infografis pada 1 Mei 2021.

Visi Misi UPT Cimahi Technopark https://www.cimahitechnopark.id/visidan-misi.html diakses pada 1 Mei 2021. 